\title{
Grey Water Irrigation: An Alternative Approach for Household Production: A Review
}

\author{
Endalkachew Abebe \\ Researcher and Lecturer, Guna Tana Integrated Field Research and Development Center, Debre Tabor \\ University, Debre Tabor, Ethiopia
}

\begin{abstract}
The need for water is growing with increasing population and the adverse impacts of climate change especially in Ethiopia. Innovative concepts and technologies are urgently needed to close the loop for water. Among the options for innovative water resources, grey water reuse is receiving crucial attention as a sustainable approach. The objective of this paper is to review the reuse of grey water for irrigation as an option for household production. The review indicated that reuse of untreated grey water in agriculture is a reality in many parts of the World where poverty restricts farmers' access to freshwater supplies. Grey water reuse for irrrigation had been also promoted in Ethiopia by different organizations as ameans of food security for low income households. According to this paper grey water can be applied by using subsurface drip irrigation, grey water tower and keyhole garden methods. Both grey water tower and keyhole garden are easy to construct and operate with low cost compared to sub surface drip irrigation. Recent studies showed that the nutrients $\mathrm{N}$ and $\mathrm{P}$ are higher in grey water imply that it can be appreciated as a means to increase crop yield. Even though grey water had apotential impact on the plant, soil and health especialy when it is contaminated with faecal and have direct contact with edible portion of the plant, recent studies showed that there is no siginificant impact of grey water irrigation on health and environment in developing countries. Experiences from global and national level showed that grey water can be managed successfully at household level and it can be apromising practice to ensure food security and to maintain good hygine practice in Ethiopia. More research is needed in our country related to grey water irrigation and its impact on health and environemnt before scaling it up at national level.
\end{abstract}

Keywords: Grey water, Grey water tower, Key hole Garden

DOI: $10.7176 /$ CER/11-2-03

Publication date:March $31^{\text {st }} 2019$

\section{Introduction}

Recently, due to climate change and drought there is international policy framework recommends the promotion of urban and peri-urban agriculture as an escape from food crisis situations. However, many households in poorer urban areas lack access to supply of fresh water (FAO, 2008).

As the world's freshwater supply becomes increasingly scarce, increased attention towards alternative water resources has become necessary. Water reuse is gaining significant momentum in discussions about sustainable water resource management, green economies, and urban planning. Grey water reuse is a promising alternative water source, which could be exploited on a continuous basis and treated for non-potable uses (Chong et al., 2015). Increasingly, grey water use is seen as an essential component of local and national efforts to adapt to climate change, enhance food security, extend potable water supply, and reduce pollutants in the environment (Drechsel et al., 2015).

Grey water is all waste water from houses except from toilets (Riderrstolpe, 2004). Grey water may be defined as that domestic wastewater produced from everyday activities arising from the use of bathtubs, hand basins, showers, laundry machines and kitchen sinks without any wastewater inputs from toilets (blackwater) (Eriksson et al., 2002).

The interest in grey water reuse has arisen Friedler, 2004; Mara, 2004) and as such may be suitable for garden or agricultural irrigation (Eriksson et al., 2006; Rodda et al., 2011). Therefore grey water reuse may offer the means to significantly reduce domestic water consumption in a two-way solution to water sustainability. Although the quality of grey water is typically poorer than that of tap water (Eriksson et al., 2002; Ottoson and Stenström, 2003), it is also generally less polluted than other municipal wastewater streams due to the relatively low content of human excreta (urine and faeces) (Pinto et al., 2010). The low organic and pathogenic loadings typical of some grey water streams also enhance its storage and reuse potential.

The notion of grey water reuse for irrigation to promote the conservation of water and the use of associated nutrients is not a new one (Rodda et al., 2011). Grey water has already been used successfully in many parts of the world to overcome shortfalls in local water supplies. Grey water contains varying concentrations of macroand micronutrients depending on the source, it has the potential to act as a dilute fertilizer (Eriksson et al., 2002). Plant nutrients present include nitrogen, phosphates, potassium (from soap, fabric softeners and detergents) which is all essential for plant growth and development.

In particular, grey water reuse has been practiced extensively in arid regions with high evaporation rates and 
low rainfall. In arable areas where rainfall is usually sufficient to support most food crops, the impetus for reuse has been less but is growing as changing climate patterns together with net growing human populations mean that growing freshwater demands are unable to be met on a consistent basis. Despite the general movement towards grey water reuse for a variety of applications, a significant risk component exists. (Eriksson et al., 2002).

Landscape and agricultural irrigation are identified as logical uses for recycled grey water (Toze, 2006). Experiences with grey water reuse for irrigation in many parts of the world have shown a general net benefit in terms of water conservation, reduction in strain on waste-water facilities, food production, and aquifer recharge (Madungwe and Sakuringwa, 2007).

Grey water reuse for irrigation is not however without its hazards, since it may contain organic and chemical compounds that can pollute the environment and pose a health risk to humans (Toze 2006; Eriksson et al., 2002). For small-scale irrigation projects, possible risk associated with grey water reuse may fall into 3 categories (Rodda et al., 2011): adverse effects on human health; adverse effects on plant growth and yield and adverse effect on the general environment, with particular reference to the ability of soil to support plant growth.

From the above contexts, the objective of this paper is to review the grey water irrigation as an option for household production as well as its potential impact on environment.

\section{Overview of Grey Water Irrgation}

\subsection{Grey Water Classification, Composition and Characteristics}

Grey water is defined as wastewater that includes water from baths, showers, hand basins, washing machines, dishwashers, and kitchen sinks, but excludes streams from toilets (Jefferson et al., 2004). Wastewater from the bathroom, including showers and tubs, is termed light grey water (Friedler and Hadari, 2006). Grey water that includes more contaminated waste and from laundry facilities, dishwashers and, in some instances, kitchen sinks is called dark grey water (Birks and Hills, 2007). The literature indicates that about $27 \%$ of grey water originates from the kitchen sink and dishwasher, $47 \%$ originates from the wash basin, bathroom, and shower, and $26 \%$ originates from laundry and the washing machine.(Jamrah et al., 2006; Ghaitidak and Yadav, 2013).

The quantity of grey water generated is dependent on the characteristics (e.g. water supply service and infrastructure, lifestyle preferences, water use patterns and age distribution) of houses which generate the effluent (Morel and Diener, 2006). The grey water quantity generated in low-income areas which experience water scarcity can be as low as 20-30 liters per person while high-income households with reticulation pipeline may generate several hundred litres per day. These quantities may even be less in regions where rivers or lakes are used for personal hygiene. Morel and Diener (2006) determined typical grey water generation quantities of $90-120 \mathrm{l} / \mathrm{p} / \mathrm{d}$ in houses with water pipeline. This range corresponds with that generated by Mandal et al. (2009), i.e. an average grey water generation of $110 \mathrm{l} / \mathrm{p} / \mathrm{d}, 80 \mathrm{l} / \mathrm{p} / \mathrm{d}$ which is generated from bathing, cloth washing and wash basins, and $30 \mathrm{l} / \mathrm{p} / \mathrm{d}$ from kitchen grey water. In general, grey water produced is about $69 \%$ of the total water consumption (Jamrah et al. 2006; Hernandez et al ,2011).

Grey water is generated as a result of the living habits of the people involved. Therefore, its characteristics are highly variable and influenced by lifestyle, the social and cultural behavior of the residents, the availability of water, and the consumption amount (Eriksson et al., 2002; Jefferson et al., 2004; Uddin et al., 2015). Grey water includes different ranges of organic matters (Halalsheh et al., 2008), suspended solids, heavy metals (Palmquist and Hanaeus, 2005), in-organic ions (Eriksson and Donner, 2009), and E.coli (Winward et al., 2008).

The physical and chemical characteristics of grey water have been widely discussed in the academic literature indicate that grey water parameters are highly variable, as expected from daily or seasonal fluctuations and the above discussed variations in quantity and quality. The ranges of electrical conductivity, turbidity, and suspended solids for dark grey water are 190-1,830 $\mu \mathrm{S} \mathrm{cm-1,19-444} \mathrm{NTU,} \mathrm{and} \mathrm{12-315} \mathrm{mgL-1,} \mathrm{respectively,}$ while for light grey water these ranges are 14-921 $\mu \mathrm{Scm}-1$, 12.6-375 NTU, and 29-505 mgL-1, respectively (Boyjoo et al., 2013). The BOD and COD concentrations are within the ranges 48-1,056 and 50-2,568 mgL-1, respectively, for dark grey water, and 20-300 and 55-633 mgL-1, respectively, for light grey water (Boyjoo et al., 2013). Kitchen grey water contains biodegradable dissolved food particles that contribute to the BOD, while the high COD concentration in dark grey water is probably due to the presence of detergents in laundry powders and dishwashing liquids (Boyjoo et al., 2013). All types of grey water show good biodegradability in terms of COD: BOD5 ratios (Li et al., 2009). Moreover, kitchen and laundry grey water are higher in both organics and physical pollutants compared to bathroom grey water. Bathroom and laundry grey water are less contaminated by microorganisms, compared to kitchen grey water. Casanova et al. (2001) found that kitchen water contributes 3-4 logs to the fecal grey water load, which might be due to the presence of large amounts of easily biodegradable organic substances in kitchen grey water. Kitchen grey water is also more contaminated by thermal-tolerant coliforms than other grey water streams (WHO-guidelines, 2006).

Recent studies also showed that the nutrients $\mathrm{N}$ and $\mathrm{P}$ are also higher in dark grey water (21-57.7 and 0.062$42 \mathrm{mgL}-1$, respectively) compared to light grey water (4.1-16.4 and 0.11-1.8 $\mathrm{mgL}-1$, respectively), due to 
kitchen grey water and phosphates from laundry detergents (Boyjoo et al., 2013). Elemental concentrations also vary according to the water quality and plumbing conditions that prevail in each country. However, it is well known that laundry detergents are a source of heavy metals such as $\mathrm{Cd}, \mathrm{Cu}, \mathrm{Pb}, \mathrm{Cr}$, and $\mathrm{Zn}$.

\subsection{Significance of Grey Water Reuse}

Grey water has been identified as a widespread problem, however, grey water contains nutrients that are beneficial to the growth of most plants, therefore one way to improve food security, in poor communities, is to re-use grey water for irrigation of food crops in a small-scale urban agriculture (Salukazana et.al, 2005).

According to Salukazana et al. (2005) grey water use in urban agriculture is potentially beneficial for a number of reasons, including: Environmental and health hazards through pooling of wastewater can be resolved; reducing the demand for potable water use for irrigation;and it contributes to poverty alleviation and food security.

\subsection{Grey Water Reuse in Agriculture}

We are now entering an era where abundant, clean freshwater is no longer guaranteed. Water scarcity is one of the most significant challenges to human health and environmental integrity (Finley et.al., 2008), an era of dwindling water resources, the treatment and reuse of wastewater is rapidly becoming a subject of great interest (WHO, 2006).

Reuse of untreated waste water in agriculture is a reality in much of the world, especially in areas where poverty restricts farmers' access to freshwater supplies (Salgot, 2003). In theory, agricultural water need not be of potable quality, opening the door to grey water irrigation (WHO, 2006). Irrigation is often the preferred enduse for reclaimed wastewater because it contains valuable nutrients required for plant growth (Exall, 2004) .

Grey water from households is used differently. Its use is practiced on an informal basis to supplement irrigation water. It also holds the potential to contribute to food security in poor communities by providing a source of both irrigation water and nutrients for crop plants (Domènech et al., 2014). In arid areas where there is dry grass, grey water is ideal for irrigating firebreaks, because it contributes plant nutrients in the process. Grey water may be used to irrigate gardens during drought periods and also to irrigate golf courses, food crops, parks, playgrounds, school yards, business parks, freeways, landscaping and pasture for animals (Andreson, 2007; Domènech et al., 2014). Several studies showed that grey water irrigation increases plant growth, crop yield without minimum/zero effect on the quality of the crop (Rusan et al., 2007).

\subsection{Trends on Grey Water Reuse International Studies}

A study conducted by Sondhia et al (2007) found out that the community in Victoria, Australia reuses grey water for toilet flushing and watering their gardens as their coping mechanisms due to unavailability of water supply. Mandal et al (2010) indicated that grey water treatment and reuse is one of the feasible options in developing countries like India to overcome food insecurity and sanitation problem. Kuntal et al (2014) reported that Indian middle-class households if recycled and reused grey water at the site of generation for toilet flushing operations, gardening purposes, it would save a significant quantity of freshwater, thereby saving significant amount of money as well as energy. Ryan et al (2009) reported that female participants and lower income residents were found to be more likely to reuse grey water on their garden, and also lower income residents resort to using grey water as their coping mechanism because they cannot afford other water saving options. Santosa et al (2012) found out that grey water reuse is a potential method to reduce potable water consumption in buildings and, therefore, to reduce wastewater discharged to public sewage systems and treatment plants. The environmental and economic benefits of such an approach are significant. Faruqui and Al-Jayyousi (2002) conducted experiments on the impact of growing food crops in rural Jordan using grey water to help create food security and generate additional income. The research showed that grey water hold a great potential. It was reported that the women who participated in this experiment said that they felt empowered by these new skill they have acquired and the ability to better provide for their families. The study did not report any significant adverse effect on the soil.

\section{Grey Water Reuse in Ethiopia}

Water is a strategically limited natural resource, and currently Ethiopia is in the grip of an extended drought period and the situation is made worse by climate change effects (Seleshi and Zanke, 2004). To cope with the current and future water scarcity in Ethiopia, we need to look for alternative water sources. Reusing of grey water (Figure 2) for irrigation and other non potable purpose will be a solution to this problems (IRC, 2013). Even in the most water scarce areas of Ethiopia, the majority of garden crops are rainfed and irrigation with grey water is not frequently applied (Scheelbeek, 2006). Various organizations have promoted the use of grey water irrigation as a means of enhancing the food production capacity of households, such as ENDA-Ethiopia, USAID and the ROSA and CLARA projects of Arba Minch University. Catholic Relief Services (CRS) also promotes vegetable gardens with partner organizations in Arba Minc, East Arsi\& East Hararghe (ROSA, 2009). But detail 
scientific investigation on the reuse, characterstics and effects of grey water irrigation has not been done in Ethiopia.
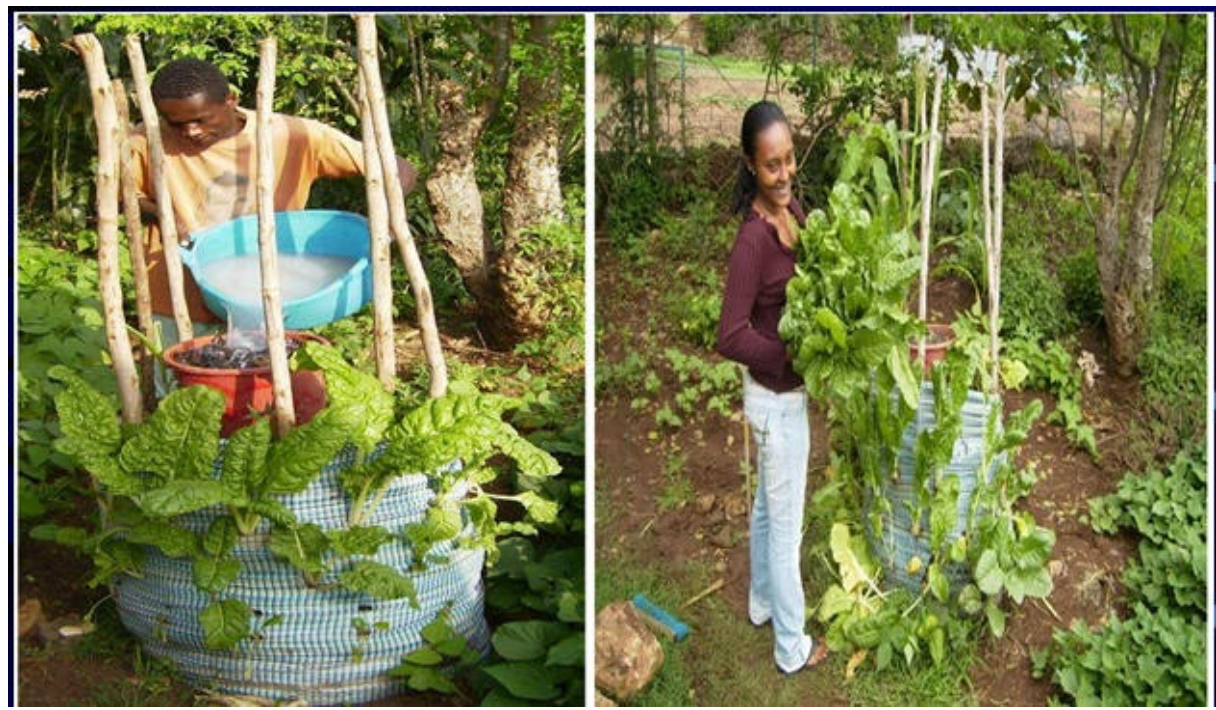

Figure 1. Grey water Tower Irrigation in Ethiopia (ROSA,2010)

Irrigation method is another factor of considerable importance in the reuse of grey water, especially with regards to microbial contamination in agricultural applications (Finley et.al., 2008). Even though ther are different methods of grey water irrigation, the widely practiced method in Ethiopia are grey water tower and key hole garden. As it stated in IWRM (2008); ROSA et al. (2006) Grey water towers (Figure 2) are cylindrical and made out of simple plastic bags or clothes. It is reinforced with wooden poles, filled with a soil mix (soil, ash and/or compost/vermicompost) and anchored into the soil. Vegetables are grown in holes cut in the sides of the bag. Each day, the available grey water is poured into the bag. The grey water tower is a circular bag which has got soil, ash and compost mixture in it and a gravel column at the center. It is used to treat and reuse grey water, water that has been used for bathing, washing clothes and utensils. Leafy plants or vegetables are planted in holes cut in the sides of the bag itself and each day the available grey water from a household is poured directly on the gravel column (ROSA et al., 2009). T A keyhole garden (Figure 3) (so-called because of its shape) is a round raised garden, supported with stones.(CRS, 2008). Keyhole gardens, is a raised (waist height) garden bed surrounded by rocks and stones, with a walkway to allow a person to sit or squat while working in the garden around them. The Grey water technology adopted in Arba Minch town by ROSA project (Shewa, 2009) revealed that grey water tower and key hole garden is a promising method of reusing grey water for irrigating vegetables in home garden in water scarce area (ROSA, 2010).

\section{Environmental and Health Impacts of Grey Water Irrigation Effects of Grey Water Reuse on Health}

Microbial and chemical contamination of grey water poses a potential risk to human health. It is important to recognize that grey water does have the potential to transmit disease. However, there are no recorded incidents of serious effects on human health from the reuse of grey water (CSBE, 2003). Direct contact of the water with edible portions is the principal transmission route of pathogens from water to crop (Gerba and Smith 2005). Jackson et al. (2006) found no significant difference in bacterial levels on plant surfaces grown in plots irrigated with grey water and tap water.

In some cases, grey water may be contaminated with faecal matter. In the ROSA project the faecal coliform concentrations in grey water were very high thus indicating a considerable contamination of grey water by human faeces (Langergraber and Weissenbacher 2010). The source of this contamination is not clear, but could come from e.g. water used to wash children's diapers. Little is known about how households dispose of their water and whether such washing water is mixed with kitchen water or 'thrown out' separately. More research needs to be done on this, before proceeding to nation-wide promotion of grey water reuse.

Even if it contains some faecal matter, the reuse of grey water should not be much of a problem for the keyhole and vertical gardens, as the water is applied to the central column for sub-surface irrigation. Moreover, gravel and other materials in the column may serve as filter. However, in the vegetable bags this contamination presents a potential health risk, as the water may be sprinkled or poured over the plants (ROSA, 2010; IRC,2013).

Effects of Grey Water Reuse on Plant and Soil

Grey water used for agricultural purposes worldwide has also been found to increase crop yield due to 
finite concentrations of essential macro-nutrients such as nitrogen (N) and phosphorus (P) contained in grey water (Rusan et al., 2007). However, it may also contain sodium and chloride, which can be harmful to some plant species (Friedler, 2004). Studies suggest that caution should be taken when sensitive crops such as pepper, potato and corn are irrigated with grey water that have a high salt concentration because it leads to severe leaf damage and crop failure (Bauder et al., 2007).

In a study conducted by Rusan et al., (2007), essential nutrients (N, P, and $\mathrm{K}$ ) contained in grey water resulted in higher plant biomass in the production of barley. However, there was no significant difference observed on plant growth parameters measured and biomass of lettuce and carrots (Finely et al., 2008; Misra et al., 2009) when irrigated with grey water compared to potable water.

Plant growth in response to grey water irrigation appears to be dependent on the type of crop and nutrient content of the irrigation water (Pinto et al., 2010). Tomatoes irrigated with grey water obtained higher nutrient uptake and biomass at the flowering stage when compared to tap water (Mirsa et al., 2009).

Grey water has both negative and positive environmental effects on soils depending on how it is managed. In rural areas, grey water is disposed directly on the ground which will cause pollution and damage on the soil. However, the organic matter contained in grey watercould help in building up organic matter in the soil over time (Rusan et al., 2007). There have been no scientic studies done on assesing the impact of grey water irrigation on plant and soil in Ethiopia, even though the grey water had been tested in different parts of Ethiopia.

\section{Conclusion}

The challenge of delivering water and sanitation services to an increasing human population is especially critical in water scarce developing countries like Ethiopia. Grey water reuse for edible crop irrigation could become a popular coping strategy in parts of the world where freshwater is in short supply and local food production is necessary to combat food insecurity. Experiences at international and national level showed that grey water can be managed successfully at household level. It can be apromising practice to ensure food security and to maintain good hygine practice in Ethiopia.

Grey water reuse can be appreciated as a valuable resource as it increases water productivity. Economic, environmental, and social benefits can be realised through water savings, increased crop production, and effective disposal. Grey water can also increase crop yield due to finite concentrations of essential macronutrients such as $\mathrm{N}$ and $\mathrm{P}$ resulted in an increased yield, and improved external and internal crop quality.

However, grey water does have the potential to transmit disease, direct contact with grey water and irrigating the edible portion through surface application should be minimized.

More research is needed related to grey water irrigation, its characterstics and composition, its methods of application and its impact on health and environemnt before scaling it up at national level.

\section{REFERENCES}

Abegaz K., no date. Presentation on keyhole garden and vegetable gardening. Addis Ababa, Ethiopia: Catholic Relief Services (CRS).

Anderson, J. L. (2007). Water awareness. In Inland Valley Daily Bulletin, Chino Hills. http:www.water awareness/water policy/docs.

Al-Mughalles, M.H., Rahman, R.A., Suja, F.B., Mahmud, M., Jalil, N., 2012. Household greywater quantity and quality in Sana'a, Yemen. EJGE 17, 1025-1034.

Birks, R., Hills, S., 2007. Characterisation of indicator organisms and pathogens in domestic greywater for recycling. Environmental monitoring and assessment 129, 61-69.

Boyjoo, Y., Pareek, V.K., Ang, M., 2013. A review of greywater characteristics and treatment processes. Water Science \& Technology 67, 1403-1424.

Casanova, L.M., Little, V., Frye, R.J., Gerba, C.P., 2001. A Survey Of The Microbial Quality Of Recycled Household Graywater. Wiley Online Library

Chong, M.N., Cho, Y.J., Poh, P.E., Jin, B., 2015. Evaluation of Titanium dioxide photocatalytic technology for the treatment of reactive Black 5 dye in synthetic and real greywater effluents. Journal of Cleaner Production 89, 196-202.

CRS - Catholic Relief Services, 2008. Homestead Gardening: A manual for program managers, implementers and practitioners. Baltimore, USA: Catholic Relief Services.

Domènech, L., March, H., Vallés, M. \& Saurí, D. 2014. Learning processes during regime shifts: Empirical evidence from the diffusion of greywater recycling in Spain. Environmental Innovation and Societal Transitions. ISSN.2210-4224. DOI: DOI: 10.1016/j.eist.2014.01.001.

Drechsel, P., Mahjoub, O., Keraita, B., 2015. Social and Cultural Dimensions in Wastewater Use. Wastewater. Springer, pp. 75-92.

Enriquez, C., Alum, A., Suarez-Rey, E.M., Choi, C.Y., Oron, G., Gerba, C.P. 2003. Bacteriophages MS2 and PRD1 in turfgrass by subsurface drip irrigation. Journal of Environmental Engineering-ASCE, 129(9), 852- 
857.

Eriksson, E., Auffarth, K., Henze, M., Ledin, A., 2002. Characteristics of grey wastewater. Urban water 4, 85104.

Eriksson, E., Baun, A., Henze, M., Ledin, A., 2006. Phytotoxicity of grey wastewater evaluated by toxicity tests. Urban Water Journal 3, 13-20.

Eriksson, E., Donner, E., 2009. Metals in greywater: sources, presence and removal efficiencies. Desalination 248, 271-278.

Exall, K. 2004. A review of water reuse and recycling, with reference to Canadian practice and potential: 2. Applications. Water Quality Research Journal of Canada, 39(1), 13-28.

Food and Agriculture Organization, 2008. Food and Agriculture Organization. 2008. Resource document. Technical report.

Friedler, E., 2004. Quality of individual domestic greywater streams and its implication for on-site treatment and reuse possibilities. Environmental Technology 25, 997-1008.

Friedler, E., Hadari, M., 2006. Economic feasibility of on-site greywater reuse in multi-storey buildings. Desalination 190, 221-234.

Gerba, C.P., and Smith, J.E. 2005. Sources of pathogenic microorganisms and their fate during land application of wastes. Journal Of Environmental Quality, 34, 42-48.

Ghaitidak, D.M., Yadav, K.D., 2013. Characteristics and treatment of greywater-A review. Environmental Science and Pollution Research 20, 2795-2809.

Halalsheh, M., Dalahmeh, S., Sayed, M., Suleiman, W., Shareef, M., Mansour, M., Safi, M., 2008. Grey water characteristics and treatment options for rural areas in Jordan. Bioresource technology 99, 6635-6641.

Hernandez Leal L, Temmink H, Zeeman G, Buisman CJN. 2011. Characterization and anaerobic biodegradability of grey water. Desalination. 2011;270:111-115.

Hyde, K. 2013. An evaluation of the theoretical potential and practical opportunity for using recycled greywater for domestic purposes in Ghana. Journal of Cleaner Production 60: 195-200

Jackson, S., Rodda, N., Salukazana, L. (2006). Microbiological assessment of food crops irrigated with domestic greywater. Water SA, 32(5), 700-704.

Jefferson, B., Laine, A., Parsons, S., Stephenson, T., Judd, S., 2000. Technologies for domestic wastewater recycling. Urban water 1, 285-292.

Jefferson, B., Palmer, A., Jeffrey, P., Stuetz, R., Judd, S., 2004. Grey water characterization and its impact on the selection and operation of technologies for urban reuse. Water Science \& Technology 50, 157-164.

Jamrah, A., Al-Omari, A., Al-Qasem, L., Ghani, N.A., 2006. Assessment of availability and characteristics of greywater in Amman. Water international 31, 210-220.

Kuntal, A. V., Meena, K. S., Akansha, B., Absar, A. K., Sudipta, S. 2014. Characterization of greywater in an Indian middle-class household and investigation of physicochemical treatment using electrocoagulation. Separation and Purification Technology 130:160-166.

Langergraber G. and Weissenbacher N., 2010. Summary of the main findings and main achievements of ROSA. Sustainable Sanitation Practice 4: 31-34. http://www.ecosan.at/ssp/issue-04-the-rosa-project.

Li, F., Wichmann, K., Otterpohl, R., 2009. Review of the technological approaches for grey water treatment and reuses. Science of the Total Environment 407, 3439-3449.

Madungwe, E. and Sakuringwa, S. 2007. Greywater reuse: A strategy for water demand management in Harare? Physics and Chemistry of the Earth, 32(15-18), 1231-1236.

Mandal, D., Labhasetwarb, P., Dhonea, S., Dubeya, A. S., Shindec, G. \& Wate, S. 2010. Water conservation due to greywater treatment and reuse in urban setting with specific context to developing countries. National Environmental Engineering and Research Institute Nagpur, India.

Mara, D.D., 2004. Domestic wastewater treatment in developing countries. Earthscan, London.

Morel A, Diener S, 2006. Greywater Management in Low and Middle-Income Countries, Review of different treatment systems for households or neighbourhoods. Swiss Federal Institute of Aquatic Science and Technology (Eawag). Dübendorf, Switzerland.

Ottoson, J., Stenström, T.A., 2003. Faecal contamination of greywater and associated microbial risks. Water Research 37, 645-655.

Palmquist, H., Hanæus, J., 2005. Hazardous substances in separately collected grey-and blackwater from ordinary Swedish households. Science of the Total Environment 348, 151-163.

Patterson, R.A., 2000. Wastewater quality relationships with reuse options. Proceedings of the $1^{\text {st }}$ World Water Congress of the International Water Association. 3-7 July, Paris, France.

Pinto, U., Maheshwari, B.L., Grewal, H.S., 2010. Effects of greywater reuse on plant growth, water use and soil properties. Resources, Conservation and Recycling 54, 429-435.

Ridderstolpe, P. (2004): Introduction to Greywater Management. EcoSanRes, Stockholm. Online internet document, URL: ttp://www.ecosanres.org/pdf_files/ESR_Publications_2004/ESR4web.pdf 
Rodda, N., Salukazana, L., Jackson, S.A.F., Smith, M.T., 2011. Use of domestic greywater for small-scale irrigation of food crops: Effects on plants and soil. Physics and Chemistry of the Earth 36, 1051-1062.

ROSA.2007.Greywater use in peri-urban households in Kitgum, Uganda. Makerere University ROSA Staff, Ka mpala, Uganda

ROSA.2010.Greywater use in peri-urban households in Arba Minch, Ethiopia. ROSA Staff, Ethiopia

Rusan MJM, Hinnawi S and Rousan L .2007. Long term effect of wastewater irrigation of forage crops on soil and plant quality parameters. Desalination $215143-152$.

Ryan, A. M., Clive L., Spash, C. L. \& Measham, T. G. 2009. Socio-economic and psychological predictors of domestic greywater and rainwater collection: Evidence from Australia. Journal of Hydrology 379: 164-171.

Salgot, M., Vergés, C., Angelakis, A.N. 2003. Risk assessment in wastewater recycling and reuse. Water science and Technology- Water Supply, 3(4), 301-308.

Salukazana L, Jackson S, Rodda N, Smith M, Gounden T, Mcloed N And Buckley C, 2005. Re-use of greywater for agricultural irrigation. Paper presented at the 3rd International Conference ofEcological Sanitation, 2326 May 2005, Durban, South Africa.

Santosa, C., Taveira-Pintob, F., Chengc, C,Y., Leited, D. 2012. Development of an experimental system for greywater reuse. Desalination 285: 301-305.

Scheelbeek P., 2005. Two containers of water a day; in quest of environmental sustainability and public health for the rural poor - Water quality, multiple uses and water division in the Lege Dini watershed area, Ethiopia; Towards a Multiple Use System Approach. MSc thesis, Wageningen University, the Netherlands.

Shewa W.A. and Geleta B.G., 2009. Case study of sustainable sanitation projects: Greywater tower for periurban areas. Arba Minch, Ethiopia: Sustainable Sanitation Alliance.

Sondhia, S. 2007. Training Manual „Advance instrumental training for the analysis of pollutants in the food commodity and water"e organized at NRCWS, Jabalpur, and DWSR.

ROSA. 2009. Case study of sustainable sanitation projects: Greywater tower for peri-urban areas. Arba Minch, Ethiopia: Sustainable Sanitation Alliance.

Sara Finley. 2008. Reuse of Domestic Greywater for the Irrigation of Food Crops. Department of Bioresource Engineering McGill University.

Toze, S. 2006. Reuse of effluent water-benefits and risks. Agricultural Water Management, 80, 147-159.

Uddin, S.M.N., Li, Z., Adamowski, J.F., Ulbrich, T., Mang, H.-P., Ryndin, R., Norvanchig, J., Lapegue, J., Wriege-Bechthold, A., Cheng, S., 2015. Feasibility of a 'greenhouse system'for household greywater treatment in nomadic-cultured communities in peri-urban Ger areas of Ulaanbaatar, Mongolia: an approach to reduce greywater-borne hazards and vulnerability. Journal of Cleaner Production.

Ukpong, E. C. \& Agunwamba, J. C. 2012. Grey Water reuse for irrigation. Applied Science and Technology 2(8): 97-113.

WHO. 2006. Guidelines for the Safe Use of Wastewater, Excreta and Greywater, Volume 4: Excreta and greywater use in agriculture, World Health Organization, WHO Press, Geneva. 